\title{
Assimilation and retention of metals in teleost and elasmobranch fishes following dietary exposure
}

\author{
Teresa Mathews ${ }^{1,3, *}$, Nicholas S. Fisher ${ }^{1}$, Ross A. Jeffree $^{2}$, Jean-Louis Teyssié ${ }^{2}$ \\ ${ }^{1}$ Marine Sciences Research Center, Stony Brook University, Stony Brook, New York 11794-5000, USA \\ ${ }^{2}$ IAEA Marine Environment Laboratory, 4 Quai Antoine Premier, MC 98000, Monaco \\ ${ }^{3}$ Present address: Institute for Radiological Protection and Nuclear Safety (IRSN), Environmental Modeling Laboratory, \\ Cadarache, Bldg 159, BP 3, 13115 St. Paul lez Durance Cedex, France
}

\begin{abstract}
In a radiotracer study designed to evaluate the fate of metals from fish prey to predator fish, we measured the trophic transfer of 7 trace elements (Am, $\mathrm{Cd}, \mathrm{Co}, \mathrm{Cr}, \mathrm{Cs}, \mathrm{Mn}, \mathrm{Zn}$ ) from juvenile Mediterranean sea bream Sparus auratus to 3 predator species, the teleosts Psetta maxima and Sparus auratus, and the elasmobranch Scyliorhinus canicula. Prey S. auratus were labeled by exposure to metal radioisotopes in solution for a period of $3 \mathrm{wk}$ and were then fed to predators, after which the metal retention in the predator was assessed. Mean assimilation efficiencies (AEs) of ingested metals in the predator fishes ranged from 6 to $15 \%$ for $\mathrm{Am}$, to 63 to $74 \%$ for $\mathrm{Cs}_{\text {; }}$ significant differences in AEs were noted between species for Co and Mn only. Efflux rate constants $\left(k_{\mathrm{e}}\right)$ of assimilated metal did not differ consistently among predators for any metals. The mean $k_{\mathrm{e}}$ ranged from $0.003 \mathrm{~d}^{-1}$ for $\mathrm{Mn}$ in $S$. canicula to $0.02 \mathrm{~d}^{-1}$ for $\mathrm{Cd}$ and $\mathrm{Cs}$ in all 3 species and for Co in S. canicula. Trophic transfer factors (TTF) for each metal were determined in predator fishes to assess the potential for metal biomagnification. TTF, calculated by dividing the product of metal $\mathrm{AE}$ and ingestion rate (IR) by $k_{\mathrm{e}}$, exceeded 1 only for $\mathrm{Mn}, \mathrm{Zn}$ and Cs. For most likely scenarios of IR and AE, TTF was $<1$ for these metals, suggesting that these metals will not biomagnify in piscivorous fishes.
\end{abstract}

KEY WORDS: Metals · Elasmobranch · Fish · Trophic transfer $\cdot$ Biomagnification

Resale or republication not permitted without written consent of the publisher

\section{INTRODUCTION}

Trace metal contamination and the trophic transfer of metals in aquatic food chains has been a subject of concern for the past half century. Because metal con-

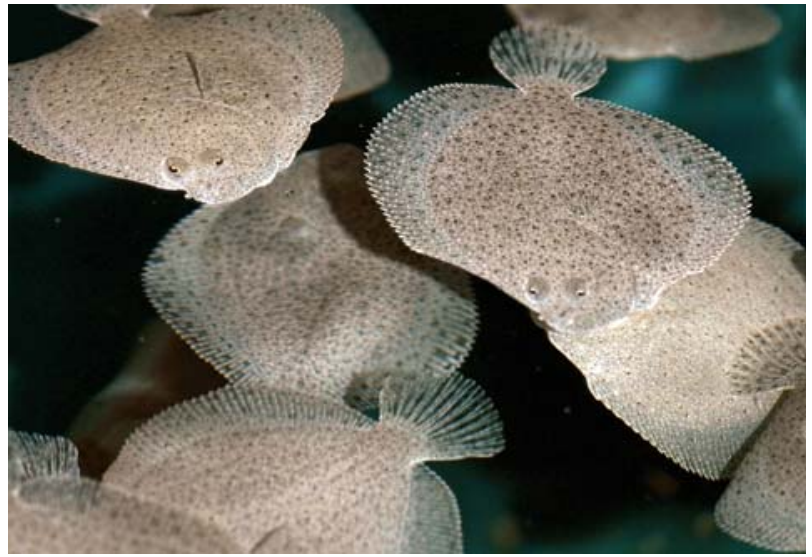

Benthic flatfishes such as the turbot Psetta maxima have been suggested as bioindicators of contaminants in marine systems.

Photo: J. L. Teyssié

centrations are often highest in organisms at the base of aquatic food chains, until recently focus has largely been on characterizing the partitioning of metals from the dissolved phase to phytoplankton cells or other particulate matter and the subsequent trophic transfer of these metals to primary consumers (Fisher \& Reinfelder 1995). An extensive database of metal accumulation and loss patterns, therefore, exists for diverse marine invertebrates (Luoma \& Rainbow 2005).

Higher trophic level carnivores have received considerably less attention in this arena, in part because trace metal concentrations and concentration factors are assumed to decrease with increasing trophic level in aquatic food chains. However, since fish can accumulate metals through both dietary and aqueous exposure to levels which may be a threat to themselves or 
the animals that consume them, a clear understanding of the mechanisms that control metal concentrations in fish is warranted. Despite the current practice of regulatory agencies developing safety guidelines to rely solely on aqueous exposure of fish to metals (USEPA 2007), trophic transfer must be considered as well, in order to understand bioaccumulation processes and the ecological and toxicological effects of metals in nature (Wang \& Fisher 1999, Luoma \& Rainbow 2005).

The assimilation and retention of metals from dietary exposure in fish differ among prey types and among different fractions in prey tissues (Reinfelder \& Fisher 1994, Zhang \& Wang 2006). Previous studies have exploited the properties of gamma-emitting radioisotopes to study metal accumulation in fish feeding on radiolabeled prey, usually crustacean zooplankton (Ni et al. 2000, Baines et al. 2002). Prey organisms are generally labeled for relatively short periods of time before being fed to predators. Such experimental conditions do not allow tissues with slowly exchanging pools of metal to accumulate sufficient radioactivity for the assessment of metal assimilation from these tissues. Metal accumulation experiments in which consumers are fed prey in which only some tissues are radiolabeled can only yield information about the trophic transfer of elements from portions of the prey (Reinfelder \& Fisher 1994). Moreover, crustacean prey have chitinous exoskeletons that are difficult to digest, and thus much of the metal associated with the carapace may pass through the gut of predator fish unassimilated (Reinfelder \& Fisher 1994). While juvenile fish often consume crustacean zooplankton as part of their diet, many adult marine fish consume an exclusively piscivorous diet.

Numerous field studies have reported metal concentrations in fish and have found great variability, both intra- and interspecifically (Hornung et al. 1993, Mason et al. 2000, Canli \& Atli 2003), but mechanistic studies are rare, and consequently the processes governing such variability remain largely unknown. In order to assess the extent to which dietary metal uptake varies between fish species, we compared the accumulation and retention of dietary metals in teleost and elasmobranch fishes. Several anatomical, physiological and life-history characteristics distinguish chondrichthyan fishes from the teleosts, many of which (cartilaginous skeleton, placoid scales, a spiral valve intestine, ureotelicity, slow growth rates, late sexual maturity, low fecundity) can potentially affect the uptake and retention of certain metals.

The quantitative assessment of metal trophic transfer in marine animals requires measurements of metal assimilation efficiencies (AE) from ingested food and the rate at which assimilated metals are lost from tissues $\left(k_{\mathrm{e}}\right)$ following dietary intake. In essence, $\mathrm{AE}$ reflects the percentage of ingested metal that crosses the gut lining and associates with specific tissues within the fish. The $k_{\mathrm{e}}$ value represents the physiological turnover rate of the assimilated metal within each fish. Using these 2 kinetic parameters, it is possible to estimate the potential for metal biomagnification in defined food chains (see Eq. 2, below). Cesium and methylmercury are the only metals that are recognized to biomagnify in aquatic food chains, but there is recent evidence to suggest that other metals such as $\mathrm{Cd}$ and $\mathrm{Zn}$ have the potential to biomagnify in certain food chains (Xu \& Wang 2002, Croteau et al. 2005, Zhang \& Wang 2007). The kinetic parameters describing metal bioaccumulation have not yet been well quantified for marine fish.

Our study compared the assimilation and retention of selected metals ( $\mathrm{Am}, \mathrm{Cd}, \mathrm{Co}, \mathrm{Cr}, \mathrm{Cs}, \mathrm{Mn}$, and $\mathrm{Zn}$ ) in a representative chondricthyan species, the spotted dogfish Scyliorhinus canicula, in a perciform species, the sea bream Sparus auratus, and in a flatfish species, the turbot Psetta maxima, to assess the trophic transfer (TTF) and biomagnification potential following dietary exposure. The 3 predator species were fed on live juvenile $S$. auratus that were radiolabeled for a period of $3 \mathrm{wk}$ to ensure uniform labeling of different tissues before being fed to predators. Metal accumulation and loss dynamics in prey fish and in different tissues in the prey were also studied. The 7 metals considered include essential (Co, Mn, Zn) and non-essential metals $(\mathrm{Am}, \mathrm{Cd}, \mathrm{Cr}, \mathrm{Cs})$ and vary in their affinity for sulfur and nitrogen, hence protein (Nieboer \& Richardson 1980); isotopes of Am, Cs, and Co are of interest as important components of radioactive wastes that have entered the oceans (Volchok et al. 1971), and $\mathrm{Cd}, \mathrm{Cr}$, and $\mathrm{Zn}$ are widely recognized contaminants in coastal waters (Kennish 1997). These metals display a wide range of assimilation efficiencies in marine herbivores (Wang \& Fisher 1999) and in fishes fed crustacean prey (Reinfelder \& Fisher 1994), but relatively little is known about their assimilation in carnivorous fishes.

\section{MATERIALS AND METHODS}

Laboratory conditions. All fishes were acclimated to laboratory conditions (water renewal rate $10 \% \mathrm{~h}^{-1}$, salinity $38 \%$, temperature $16^{\circ} \mathrm{C}$ ) for at least 1 mo prior to the start of experiments. Juvenile Sparus auratus, used as prey $(\mathrm{n}=500)$, were obtained from a hatchery in Monaco as 1 mo old hatchlings; they were fed freshly hatched Artemia salina both before and during the experiments. At the start of the experiments, the prey had an average length of $2 \mathrm{~cm}$ and an average wet weight of $0.2 \mathrm{~g}$. Immature Scyliorhinus canicula (mean wet weight $8 \mathrm{~g}$ ), Psetta maxima (mean wet 
weight $27 \mathrm{~g}$ ), and $S$. auratus (mean wet weight $12 \mathrm{~g}$ ) were chosen for similar size, mass, age, and benthic feeding habits, to constrain some of the potentially confounding effects of these variables on contaminant biokinetics.

Prey. Fish were exposed to radioisotopes held in the dissolved phase $(<0.2 \mu \mathrm{m})$ in filtered Mediterranean seawater. These fish were kept in a well-aerated, 1201 aquarium into which the radioisotopes were added daily for the first week, and then every other day for the remainder of the uptake period in order to ensure constant exposure. Mediterranean seawater from Monaco harbor was renewed between radioisotope additions.

Prey fish were fed after seawater renewal and just prior to isotope addition to prevent labeling of food. Uptake and loss of isotopes were measured in 12 individual fish, which were isolated by placement in separate plastic mesh containers. These containers were large enough for fish to swim freely and allowed radiolabeled water to flow through. Prey fish were labeled for 3 wk as described above, during which the radioactivity associated with both the water and fish were measured after each new addition of radioisotope. Fish were weighed prior to radioanalysis in order to assess dilution of metal concentration in tissue due to growth. At the end of the uptake period, 2 to 4 prey fish were fed to each predator fish, while the remainder was used for determining the retention of assimilated metal by following depuration from the prey over time.

During the depuration period, the prey fish were kept in flowing seawater (water renewal rate $10 \% \mathrm{~h}^{-1}$ ) and the loss of radioactivity from these fish was measured daily for the first week and periodically thereafter. At 1 wk intervals, 5 prey fish were selected at random and dissected into 3 compartments (head, including gills; viscera; and body, including muscle, skin, and skeleton) and radioactivity associated with each compartment was determined. In this way, we were able to obtain $k_{\mathrm{e}}$ values for each of the 3 compartments to help determine whether retention of metals was uniform or varied between different tissues.

Predators. Fishes were held in fully aerated, opencirculation, $70 \mathrm{l}$ aquaria and exposed to metals only through their diet of radiolabeled prey. Scyliorhinus canicula $(\mathrm{n}=6)$ were all kept in the same aquarium and were distinguished by spotting patterns on dorsal fins. Psetta maxima and Sparus auratus (n = 12 each) were kept in $70 \mathrm{l}$ aquaria, 3 individuals of each species in each aquarium, and were identified by slits cut in caudal fins. Both P. maxima and $S$. auratus fed on live, labeled prey fish, while $S$. canicula received freshly killed (asphyxiated) prey fish, because our observations for this species indicated limited ability to capture live prey. Radioactivity of predator fishes was mea- sured after radioactive feeding, and predators then fed on unlabeled prey for an additional $3 \mathrm{wk}$. This was sufficient time to purge their guts of unassimilated food (egested in feces, representing rapid loss from the fish) and to follow the more gradual loss of assimilated metal over time (slower loss from the fish). The radioactivity of each fish was assessed periodically during this depuration period. In the depuration period following the feeding on radioactive food, the patterns of loss of metal from predator fishes were analyzed to determine the assimilation efficiency and efflux rate for each radioisotope.

Radioisotopes and radioanalysis. We used high specific activity radioisotopes obtained from Amersham $\left({ }^{51} \mathrm{Cr},{ }^{57} \mathrm{Co},{ }^{134} \mathrm{Cs},{ }^{109} \mathrm{Cd},{ }^{241} \mathrm{Am}\right)$ and Isotope Products $\left({ }^{54} \mathrm{Mn},{ }^{65} \mathrm{Zn}\right)$. Isotopes were dissolved in $0.1 \mathrm{~N} \mathrm{HCl}(\mathrm{Cd}$, $\mathrm{Mn}, \mathrm{Co}), 0.5 \mathrm{~N} \mathrm{HCl}(\mathrm{Zn}), 3 \mathrm{~N} \mathrm{HNO}_{3}(\mathrm{Am})$, saline solution $(\mathrm{Cr})$, or aqueous solution $(\mathrm{Cs})$. For each addition, microliter additions of isotopes were added to seawater in the prey fish tank to yield the following activities: $0.5 \mathrm{~Bq} \mathrm{ml}^{-1}$ for ${ }^{241} \mathrm{Am} 1 \mathrm{~Bq} \mathrm{ml}^{-1}$ for each of ${ }^{57} \mathrm{Co}{ }^{54} \mathrm{Mn}$, and ${ }^{65} \mathrm{Zn}_{\text {; } 1.5 \mathrm{~Bq} \mathrm{ml}}{ }^{-1}$ for ${ }^{51} \mathrm{Cr} ; 2 \mathrm{~Bq} \mathrm{ml}{ }^{-1}$ for ${ }^{134} \mathrm{Cs}_{\text {, and }}$ $5 \mathrm{~Bq} \mathrm{ml}^{-1}$ for ${ }^{109} \mathrm{Cd}$, corresponding to the following concentrations: $4.6 \mathrm{fM}{ }^{241} \mathrm{Am}, 0.1 \mathrm{pM}{ }^{57} \mathrm{Co}, 83.4 \mathrm{pM}{ }^{54} \mathrm{Mn}$, $10.1 \mathrm{pM}{ }^{65} \mathrm{Zn}, 1.1 \mathrm{nM}{ }^{51} \mathrm{Cr}, 1.4 \mathrm{nM}{ }^{134} \mathrm{Cs}$, and $3.4 \mathrm{pM}$ ${ }^{109} \mathrm{Cd}$. These additions were below ambient surface seawater concentrations for all metals except Am. No change in $\mathrm{pH}$ in seawater in the prey fish tank was detected after isotope addition.

Radioactivity in all samples was determined using a high-resolution $\gamma$ spectrometry system consisting of 4 coaxial Germanium (N- or P-type) detectors (EGNC 33-195-R, Intertechnique) connected to a multi-channel analyzer (Interwinner6, Intertechnique). The radioactivity of samples was determined by comparison with the radioactivity in standards of appropriate geometry and was corrected for background and decay. To minimize errors in gamma counting due to sample geometry, movement of fish within counting chambers was limited by placing a minimal amount of water in chambers, and in the case of Sparus auratus by constraint with a semi-circular tube. Gamma emissions of $\mathrm{Am}, \mathrm{Cr}, \mathrm{Co}, \mathrm{Cs}, \mathrm{Cd}, \mathrm{Mn}$, and $\mathrm{Zn}$ were assayed at $60,320,122,605,88,835$, and $1116 \mathrm{keV}$, respectively. Counting times were adjusted to yield counting errors $<5 \%$ where possible, or to a maximum of $15 \mathrm{~min}$.

Kinetic modeling of metal bioaccumulation. The bioaccumulation of metals in fish can be explained as a balance between metal uptake and loss rates and can be described by the following equation:

$$
C_{\mathrm{ss}}=\left[\left(k_{\mathrm{u}} \times C_{\mathrm{w}}\right)+\left(\mathrm{AE} \times \mathrm{IR} \times C_{\mathrm{f}}\right)\right] /\left(k_{\mathrm{e}}+g\right)
$$

where $C_{\mathrm{ss}}$ is the steady-state metal concentration in a predator, $k_{\mathrm{u}}$ is the metal uptake rate constant, $C_{\mathrm{w}}$ is the metal concentration dissolved in the water, $\mathrm{AE}$ is the 
assimilation efficiency of the ingested metal in the animal, IR is the weight-specific ingestion rate of prey, $C_{\mathrm{f}}$ is the metal concentration in the prey, $k_{\mathrm{e}}$ is the efflux rate constant of the metal out of the predator, and $g$ is the growth rate constant of the predator (Thomann 1980, Wang et al. 1996).

Rearranging this equation to express a ratio of metal concentration in an organism in relation to the concentration in its prey allows for the assessment of the potential of a metal to biomagnify at different sequential steps in the food chain. This ratio is the trophic transfer factor (TTF) and can be calculated for a specific link in the food chain in which a predator consumes metal in prey as follows:

$$
\mathrm{TTF}=(\mathrm{AE} \times \mathrm{IR}) /\left(k_{\mathrm{e}}+g\right)
$$

A TTF $>1$ indicates a possibility of biomagnification, and TTF $<1$ suggests that biomagnification is unlikely (Reinfelder et al. 1998). For these TTF calculations we considered a range of IR likely to be encountered by fish under natural conditions (0.005 to $0.05 \mathrm{~g} \mathrm{~g}^{-1} \mathrm{~d}^{-1}$ ). Efflux rate constants are assumed to be fairly constant under diverse environmental conditions, and so mean values were used in all cases. Assimilation efficiencies of ingested metals vary with food composition and quantity, metal concentration in the food, physiological state of the animal as influenced by diverse environmental factors (Wang \& Fisher 1997), and so the range of AE values we determined is included in our calculations.

\section{RESULTS}

\section{Metal accumulation and loss in prey fish}

Patterns of accumulation of waterborne metals in juvenile Sparus auratus differed among metals and are shown in Fig. 1. $\mathrm{Cd}$ and $\mathrm{Cr}$ showed a rapid initial uptake within the first $24 \mathrm{~h}$, but then no appreciable uptake thereafter, whereas the accumulation of Am and Cs continued for the first $10 \mathrm{~d}$ before equilibrium was reached between metal concentration in the prey and the ambient water. In contrast, Co, Mn, and $\mathrm{Zn}$ showed linear uptake for the duration of the experiment. Uptake rate constants $\left(k_{\mathrm{u}}, \mathrm{l} \mathrm{g}^{-1} \mathrm{~d}^{-1}\right)$ were calculated as the slope of the linear portion of the curve
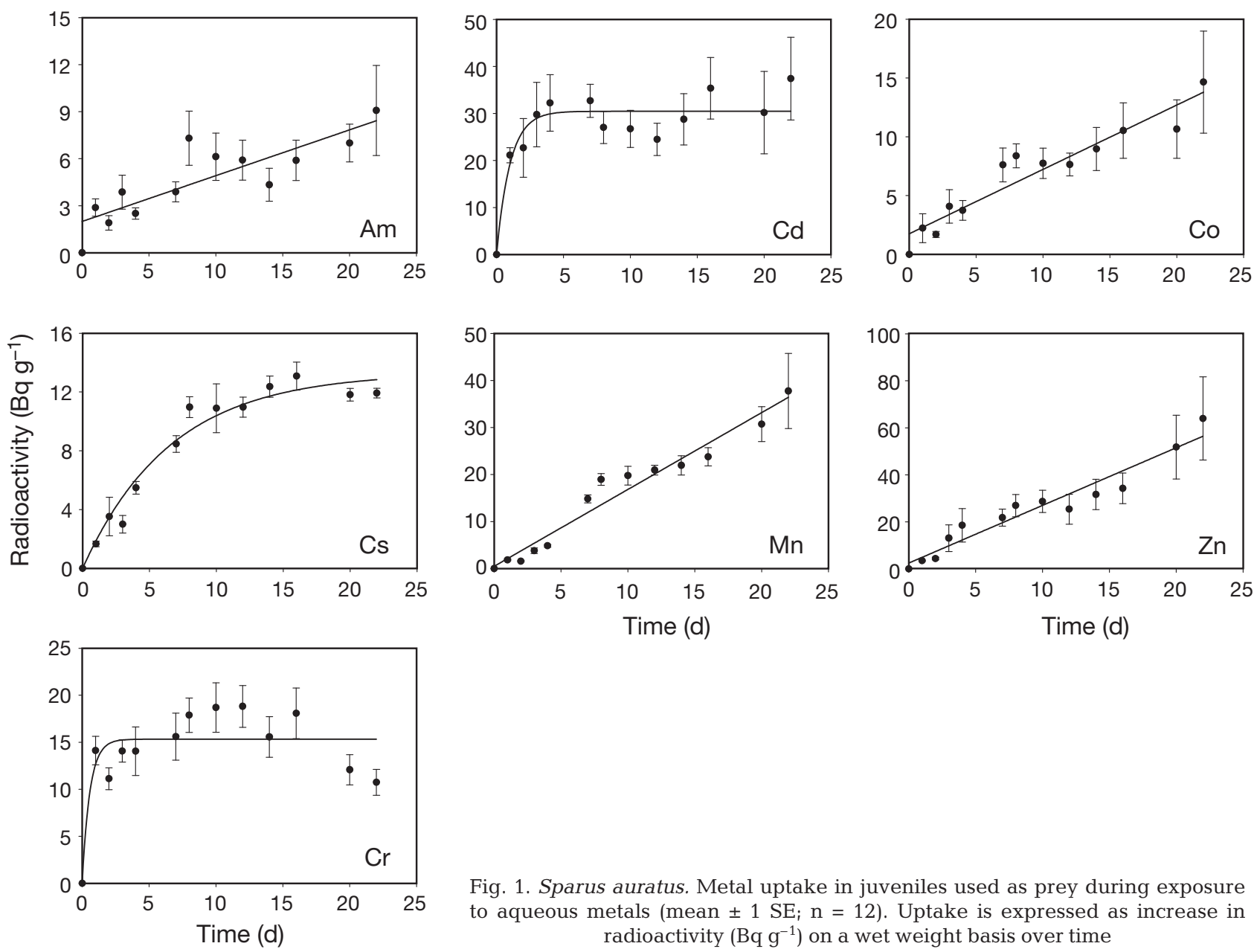

Fig. 1. Sparus auratus. Metal uptake in juveniles used as prey during exposure to aqueous metals (mean $\pm 1 \mathrm{SE}_{;} \mathrm{n}=12$ ). Uptake is expressed as increase in radioactivity $\left(\mathrm{Bq} \mathrm{g}^{-1}\right)$ on a wet weight basis over time 
Table 1. Sparus auratus. Metal uptake and loss in juveniles used as prey following exposure to aqueous metals. Regression equations represent the relationship between metal concentration $\left(\mathrm{Bq} \mathrm{g}^{-1}\right)$ and fish length $(\mathrm{cm})$ shown in Fig. $2 ; \mathrm{n}=12$ in all cases

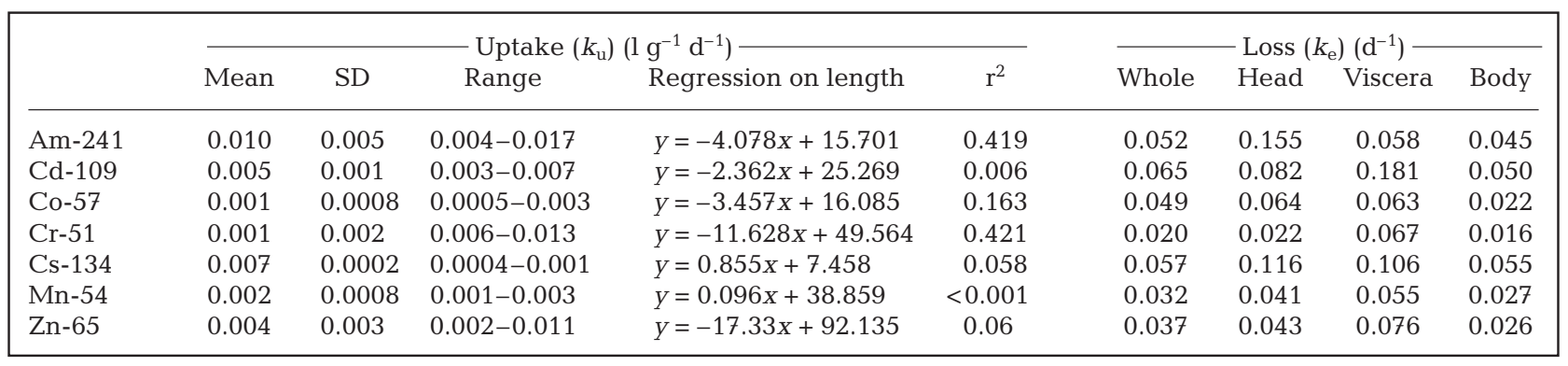

describing metal uptake in individual $S$. auratus divided by dissolved concentrations for each metal over time (Table 1). For example, for $\mathrm{Cd}$ and $\mathrm{Cr}, k_{\mathrm{u}}$ values were calculated over the first $24 \mathrm{~h}$ period. The mean $k_{\mathrm{u}} \mathrm{s}$ ranged from $0.0007 \mathrm{l} \mathrm{g}^{-1} \mathrm{~d}^{-1}$ for Cs to $0.010 \mathrm{l}$ $\mathrm{g}^{-1} \mathrm{~d}^{-1}$ for Am. While whole-body radioactivity (Bq) in the prey generally increased with fish length, these positive relationships were significant $(p<0.05)$ only for $\mathrm{Mn}$ and $\mathrm{Cs}$. There was no significant relationship between whole body concentration $\left(\mathrm{Bq} \mathrm{g}^{-1}\right)$ and fish length for $\mathrm{Cd}, \mathrm{Cs}$, or any of the essential metals, but there was a significant decrease in both $\mathrm{Am}$ and $\mathrm{Cr}$ with fish length ( $p<0.05)$ (Fig. 2). Equations and $r^{2}$ values describing the relationship of metal concentrations in $S$. auratus $\left(\mathrm{Bq}^{-1}\right)$ as a function of fish length are given in Table 1.

Analysis of dissected tissues revealed that, at the end of the uptake period, the greatest fraction of total body metal was generally found in the gut, where percentages ranged from $30 \%$ for Cs to $67 \%$ for Am (Fig. 3). At
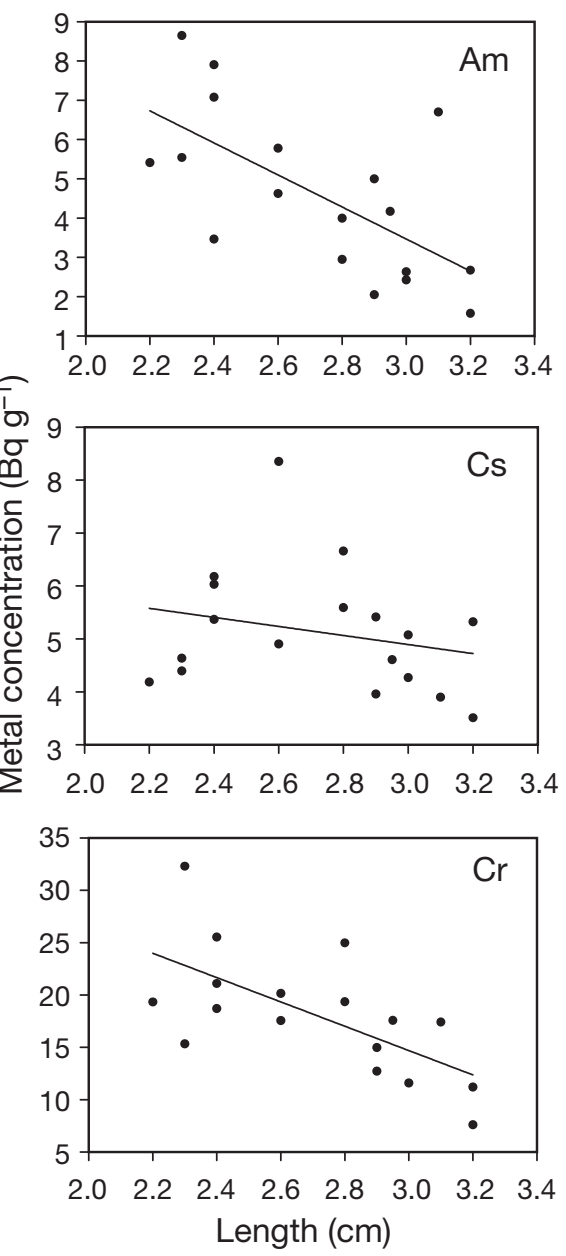
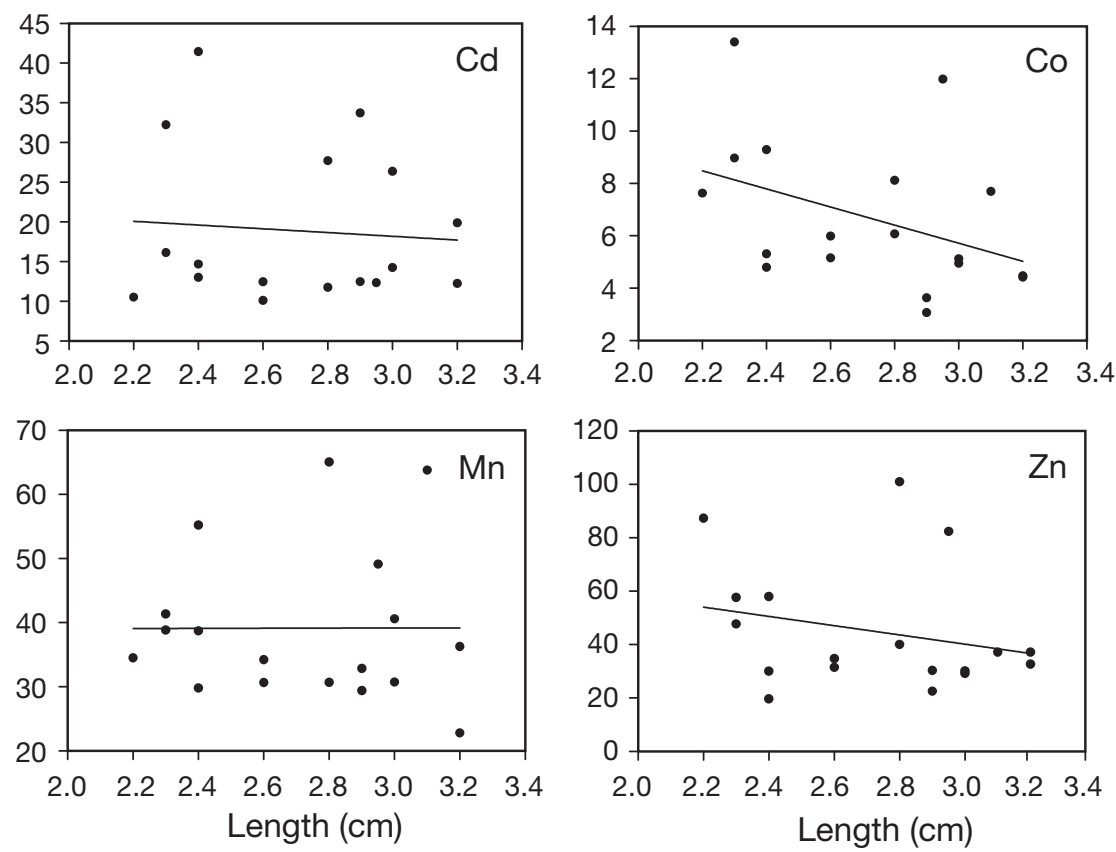

Fig. 2. Sparus auratus. Relationships between isotope concentration (Bq $\mathrm{g}^{-1}$ ) and fish length $(\mathrm{cm})$ in juveniles used as prey after 3 wk exposure to aqueous metals. Equations describing these relationships are given in Table 1 

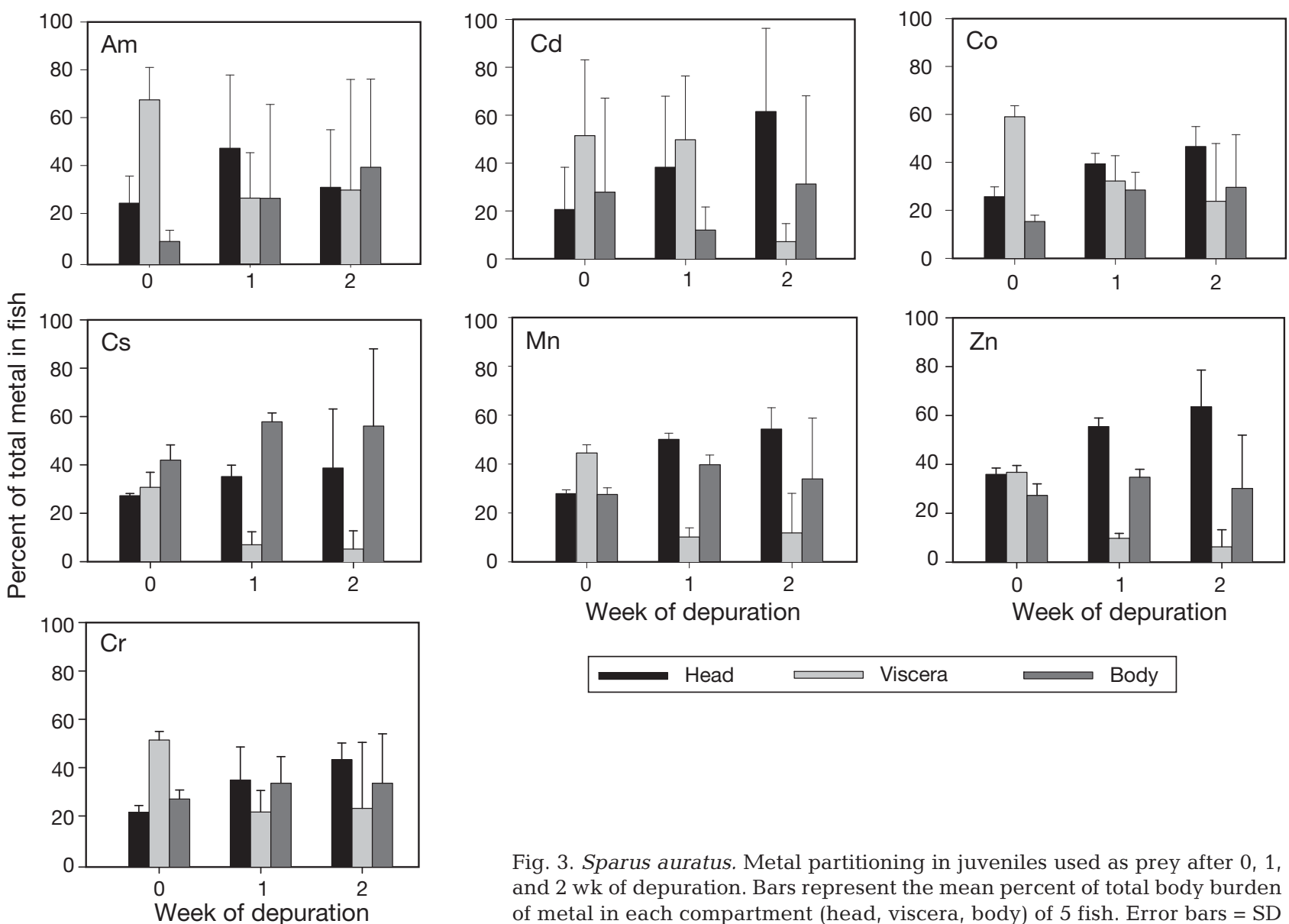

Fig. 3. Sparus auratus. Metal partitioning in juveniles used as prey after 0, 1, and $2 \mathrm{wk}$ of depuration. Bars represent the mean percent of total body burden of metal in each compartment (head, viscera, body) of 5 fish. Error bars $=$ SD

the end of the 2 wk depuration period, Cs was the only metal that remained proportionally highest in the muscle tissue. We compared loss rates of metals from whole fish and from individual compartments (head, viscera, body). Efflux rates $\left(k_{\mathrm{e}}\right)$ from whole fish ranged from $0.020 \mathrm{~d}^{-1}$ for $\mathrm{Cr}$ to $0.065 \mathrm{~d}^{-1}$ for $\mathrm{Cd}$; efflux rates from the head ranged from $0.022 \mathrm{~d}^{-1}$ for $\mathrm{Cr}$ to $0.155 \mathrm{~d}^{-1}$ for Am; efflux rates from the viscera ranged from 0.055 $\mathrm{d}^{-1}$ for $\mathrm{Mn}$ to $0.181 \mathrm{~d}^{-1}$ for $\mathrm{Cd}$; efflux rates from the body ranged from $0.016 \mathrm{~d}^{-1}$ for $\mathrm{Cr}$ to $0.055 \mathrm{~d}^{-1}$ for Cs (Table 1). Efflux rates from the viscera were consistently greater than or equal to whole fish efflux rates, and were, in general, among the highest of all the compartments, with the exception of Am. Efflux rates from the head were consistently higher than efflux rates from the body, which were consistently the lowest of the 3 compartments examined.

\section{Predator fishes}

Following pulse feeding on radiolabeled prey, loss of most of the radioisotopes from the fish was best described by a 2-compartment exponential model, with rapidly lost material being egested in fecal matter generally within $1 \mathrm{~d}$ for Psetta maxima and Sparus auratus, and about $4 \mathrm{~d}$ for Scyliorhinus canicula (Fig. 4), after which a slower loss (defined as $k_{\mathrm{e}}$ ) presumably represented assimilated radioisotope that was physiologically turned over by the fish. Cs was the exception to this pattern, showing a slow, 1-compartment loss for all 3 fish species. Because we were not able to recover feces for each individual fish, the time required for complete digestion and assimilation of the metals was not determined in the present study. The metal AEs were calculated as the $y$-intercept of the slowly exchanging pool's loss curve ( 2 to $21 \mathrm{~d}$ for the teleosts and 4 to $21 \mathrm{~d}$ for $S$. canicula), as described in Wang \& Fisher (1999). The mean AEs ranged from $8 \%$ for Am to $63 \%$ for Cs in P. maxima, from $8 \%$ for Am to $74 \%$ for Cs in S. auratus, and from $6 \%$ for Am to $73 \%$ for Cs in $S$. canicula (Table 2). The mean $k_{\mathrm{e}} \mathrm{s}$ in $P$. maxima ranged from $0.004 \mathrm{~d}^{-1}$ for $\mathrm{Zn}$ to $0.019 \mathrm{~d}^{-1}$ for $\mathrm{Cd}, \mathrm{Cs}$, and $\mathrm{Mn}$; in $S$. auratus $k_{\mathrm{e}} \mathrm{s}$ ranged from $0.006 \mathrm{~d}^{-1}$ for $\mathrm{Zn}$ and Co to $0.019 \mathrm{~d}^{-1}$ for $\mathrm{Am} ; k_{\mathrm{e}} \mathrm{S}$ in $S$. canicula ranged from $0.003 \mathrm{~d}^{-1}$ for Mn to $0.017 \mathrm{~d}^{-1}$ for Co (Table 2). Levels of $\mathrm{Cr}$ in predator fish were not high enough to calculate AE or $k_{\mathrm{e}}$ values. 

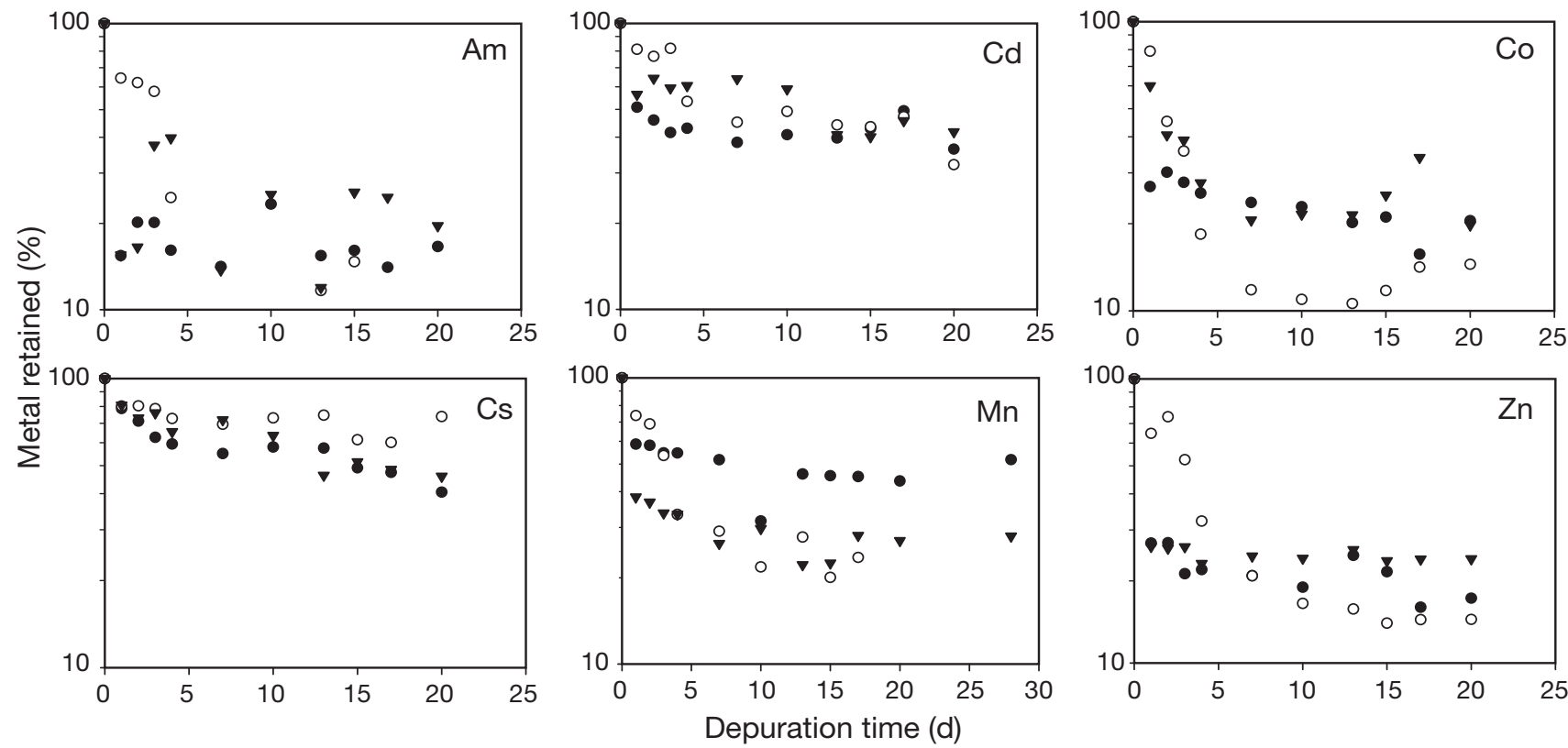

Fig. 4. Psetta maxima, Sparus auratus, Scyliorhinus canicula. Metal retention in predator fishes after pulse feeding on prey fish. Retention is expressed as percent of initial body burden of metal; data points denote means of replicate fish. $\bullet: P$. maxima $(\mathrm{n}=12)$;

จ: $S$. auratus $(\mathrm{n}=12)$; O: $S$. canicula $(\mathrm{n}=6)$

For each of the metals considered, TTFs calculated using Eq. (2) for a range of IR were similar among all 3 predator species (Fig. 5). TTFs were always $<1$ for Am, $\mathrm{Cd}$, and Co regardless of AE or IR. Mn and Cs TTFs

Table 2. Psetta maxima, Sparus auratus, Scyliorhinus canicula. Assimilation efficiencies (AE) and efflux rate constants $\left(k_{\mathrm{e}}\right)$ for $\mathrm{Am}, \mathrm{Cd}, \mathrm{Co}, \mathrm{Cs}, \mathrm{Mn}, \mathrm{Zn}$ in 3 fish species feeding on fish prey. Mean values $\pm 1 \mathrm{SE}$ are shown for both $\mathrm{AE}$ and $k_{\mathrm{e}}$ values as is the range of $\mathrm{AE}$ values observed (used to calculate trophic transfer factors [TTFs] in Fig. 5). nd.: no data

\begin{tabular}{|lccccc|}
\hline \multicolumn{3}{c}{ AE (\%) } & \multicolumn{3}{c|}{$k_{\mathrm{e}}\left(\mathrm{d}^{-1}\right)$} \\
& Mean & SE & Range & Mean & SE \\
\hline P. maxima & & & & & \\
Am & 8 & 2 & $2-17$ & 0.010 & 0.005 \\
Cd & 36 & 6 & $19-80$ & 0.019 & 0.006 \\
Co & 27 & 2 & $19-39$ & 0.013 & 0.016 \\
Cs & 63 & 2 & $58-76$ & 0.019 & 0.003 \\
Mn & 44 & 2 & $37-63$ & 0.019 & 0.005 \\
Zn & 22 & 2 & $5-35$ & 0.004 & 0.008 \\
S. auratus & & & & & \\
Am & 8 & 1 & $7-9$ & 0.012 & 0.004 \\
Cd & 45 & 5 & $30-63$ & 0.016 & 0.005 \\
Co & 21 & 2 & $14-28$ & 0.006 & 0.009 \\
Cs & 74 & 3 & $64-89$ & 0.017 & 0.003 \\
Mn & 25 & 3 & $13-36$ & 0.007 & 0.003 \\
Zn & 18 & 4 & $12-24$ & 0.006 & 0.004 \\
S. canicula & & & & & \\
Am & 6 & 1 & $3-11$ & nd & nd \\
Cd & 29 & 4 & $22-34$ & 0.009 & 0.002 \\
Co & 11 & 3 & $2-16$ & 0.022 & 0.002 \\
Cs & 73 & 4 & $60-86$ & 0.008 & 0.004 \\
Mn & 27 & 3 & $22-34$ & 0.003 & 0.003 \\
Zn & 17 & 1 & $12-19$ & 0.012 & 0.014 \\
\hline
\end{tabular}

were consistently $<1$ for the teleosts, but were $>1$ for Scyliorhinus canicula at higher IR, over the range of observed AEs. Zn TTFs were consistently <1 for Sparus auratus and $S$. canicula, but were $>1$ for Psetta maxima at the highest observed AE and at the higher IR.

\section{DISCUSSION}

\section{Metal accumulation and loss in prey fish}

The patterns of aqueous metal uptake that we observed in $S$. auratus can be related to the biological function of the metals. The essential metals $\mathrm{Zn}, \mathrm{Co}$, and $\mathrm{Mn}$ all exhibited linear uptake for the $3 \mathrm{wk}$ exposure period, i.e. these metals did not equilibrate between the ambient water and fish tissue. This may partially represent isotopic equilibration between the radioisotopes and their stable metal counterparts already in the fish tissues, a consequence of any shortterm (relative to the animal's life span) experiments involving radioisotopes. $\mathrm{Cd}$ and $\mathrm{Cr}$, which have no known function in marine fishes, appeared to reach steady state within $1 \mathrm{~d}$, whereas non-essential Am took somewhat longer to equilibrate. While Cs also has no known biological function, its capacity to act as an analogue for $\mathrm{K}^{+}$could explain why uptake continued for $10 \mathrm{~d}$ before a steady state was reached.

The uptake rate constants that we found in juvenile Sparus auratus are an order of magnitude higher than those reported by Jeffree et al. (2006) for the same 

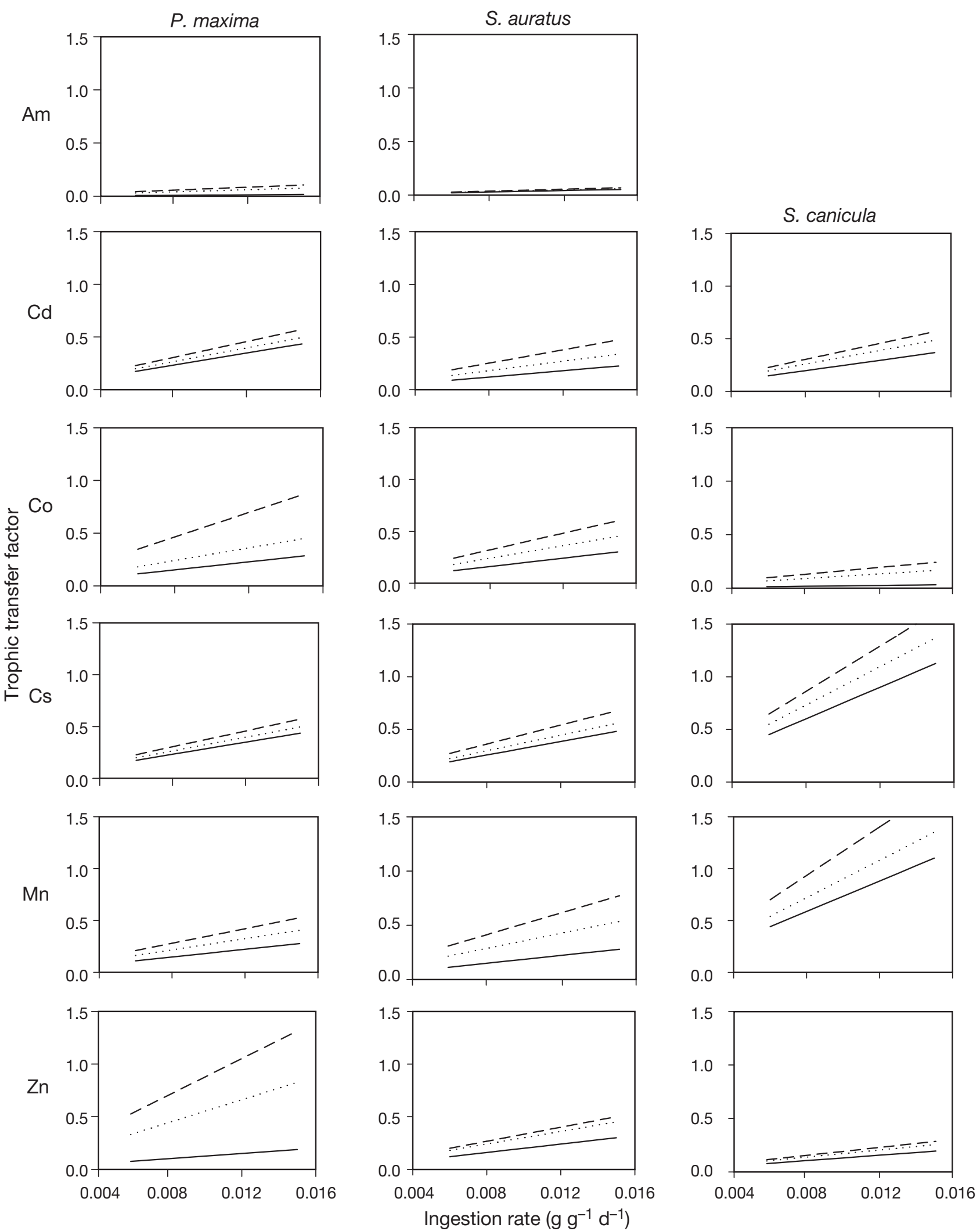

Fig. 5. Psetta maxima, Sparus auratus, Scyliorhinus canicula. Trophic transfer factors for predator fishes fed prey fish at different assimilation efficiencies (AE) and ingestion rates. High AE (dashed line), mean AE (dotted line), and low AE (solid line) values are reported in Table 2 
metals (except Cs and Cr) in Scyliorhinus canicula and Psetta maxima. We attribute these differences to differences in the size (and therefore metabolic rates) of the fish, as well as to inter-specific differences. Almost all characteristics of organisms vary predictably with body mass and can be described by power functions of the form:

$$
Y=Y_{0} M^{b}
$$

where $Y$ is some biological variable (in this case $k_{\mathrm{u}}$ ), $Y_{0}$ is a normalization constant characteristic of the organism, $M$ is the body mass of the organism, and $b$ is the allometric scaling exponent (Peters 1983, SchmidtNielsen 1984). The allometric exponent is generally found to scale as multiples of one-fourth and for metabolic rates is accepted to be 0.75 (Brown et al. 2004, Savage et al. 2004). In using this simple relationship and the mean body mass of the fish used in the 2 studies $(0.2 \mathrm{~g}$ for the fish used in our study and $6.1 \mathrm{~g}$ in Jeffree et al. 2006), we find that our $k_{\mathrm{u}}$ values for the essential metals $\mathrm{Zn}, \mathrm{Co}$, and $\mathrm{Mn}$ are comparable to Jeffree et al.'s (2006) values adjusted for differences in fish size. Thus, for comparably sized fish, Jeffree et al.'s (2006) adjusted $k_{\mathrm{u}}$ for Zn $\left(0.005 \mathrm{l} \mathrm{g}^{-1} \mathrm{~d}^{-1}\right)$, Co $\left(0.002 \mathrm{l} \mathrm{g}^{-1}\right.$ $\left.\mathrm{d}^{-1}\right)$, and $\mathrm{Mn}\left(0.003 \mathrm{l} \mathrm{g}^{-1} \mathrm{~d}^{-1}\right)$ were within the range of values observed in our study (Table 1 ). This agreement in adjusted $k_{\mathrm{u}}$ values for the essential metals in these 2 studies is consistent with the idea that their accumulation from the aqueous phase is tied to metabolic rate, unlike the non-essential metals examined, which did not show any consistent scaling trend. Hendriks \& Heikens (2001) also found that uptake from the aqueous phase of the essential metals $\mathrm{Zn}$ and $\mathrm{Mn}$ in aquatic animals had an allometric scaling exponent of 0.73 to 0.78, unlike non-essential metals, which had significantly different values.

Numerous studies have used the positive correlation of body size of an organism and tissue metal concentration as an indication of biomagnification. These were usually based on field studies that considered tissue metal concentrations in organisms exposed to metals naturally from both aqueous and dietary routes. In contrast to the relationship between fish size and metal uptake rates (of the essential metals) discussed above, we found no significant positive relationship between whole body concentrations of any of the metals investigated and size of Sparus auratus when exposed to metals only in the aqueous phase. The decrease in concentration of Am and Cr with increasing fish length suggests that the surface area to volume ratio of the fish may be a factor controlling the uptake of these non-essential metals. The lack of relationship between fish size and concentration for the essential metals is consistent with the idea that these metals are regulated metabolically.
The tissue distribution data for Sparus auratus show that the fraction of metal in different compartments changed over time, and the efflux rates from the different compartments show that these changes occurred at different rates for the different compartments, suggesting that there were likely multiple pools of metal within the fish with different turnover times. Dissections after 1 and 2 wk of depuration suggest a redistribution of metals from the gut to the other compartments of the fish, particularly the head. The greater efflux rates from the viscera than from the other compartments could be due to the fact that metals are absorbed from the gut and moved through the bloodstream into the other compartments. In addition, or alternatively, metals may be lost more rapidly from the gut than from other compartments; note that metal was acquired by these fish solely from the aqueous phase, so loss from the gut does not represent loss via egestion.

\section{Metal assimilation and retention in predator fishes}

Although there are very few studies that report the kinetic parameters of metal bioaccumulation for marine fish, in general, our observed ranking of metal assimilability ( $\mathrm{Cs}>\mathrm{Cd}>\mathrm{Mn}>\mathrm{Zn}>\mathrm{Co}>\mathrm{Am}$ ) is consistent with previous observations (Ni et al. 2000, Zhao et al. 2001, Baines et al. 2002). Note, however, that the AE values we report here are considerably higher than those found for fish feeding on invertebrate prey, especially for $\mathrm{Cd}$, which was 10 to 15 times higher in fish prey than for crustacean prey (Reinfelder \& Fisher 1994) and 3 to 5 times higher than for molluscan prey (Xu \& Wang 2002). To our knowledge, these are the first $\mathrm{AE}$ values reported for $\mathrm{Mn}$ in marine fish.

We attribute the higher AEs observed in this study in part to the partitioning of metals into soluble and insoluble fractions in different prey fish tissues. In crustaceans, metals are partitioned into dissolved internal pools and an exoskeleton, while mollusks may store metals in insoluble granules. Recent work highlights the difference in subcellular distribution of metals in crustacean, molluscan, and fish tissues (Seebaugh \& Wallace 2004). Findings suggest that metals (Cd and $\mathrm{Zn}$, in this case) associate with trophically available proteins to a greater extent in fish than in invertebrate tissues (Zhang \& Wang 2006), consistent with the higher $A E$ values measured in prey fish.

In addition to differences in bioavailability of metals in different prey items, the high AEs observed in the predator fishes could also be attributed to the size of the predators used in the present study. Because of size limitations of the gamma detectors commonly used and the infrastructure needed to house and maintain larger 
fish, most radiotracer studies with fishes have been constrained to use larvae or very small juveniles (wet weight $<2 \mathrm{~g}$ ). Our study examines assimilation of metals in fishes that range from 8 to $30 \mathrm{~g}$ wet weight, up to 10-fold higher than fishes in previous studies (Reinfelder \& Fisher 1994, Baines et al. 2002, Xu \& Wang 2002). As with other kinetic parameters, metal assimilation efficiencies increase significantly with increasing size of fish (Zhang \& Wang 2007), which could be due in part to the concurrent decrease in IR.

The 2 species of teleost fish display typical biphasic depuration curves, with a rapid initial loss of metal corresponding to gut clearance followed by a longer period of slow loss representing physiological turnover, whereas $S$. canicula took several days for gut evacuation. A gut passage time (GPT) of several days is consistent with previous findings in elasmobranchs, but the sequence of digestion and food evacuation in sharks has not yet been fully characterized. The prolonged passage of food through the digestive tract is thought to be due to enzymatic limitation in elasmobranchs, thus requiring the spiral valve intestine to hold food longer in order to digest it and absorb nutrients at levels comparable to those in teleosts (Wetherbee \& Cortes 2004).

Despite the apparent difference in GPT between the teleosts and Scyliorhinus canicula, the assimilation of metals among the different fish species was similar for most metals (Table 2). In fact, there was no significant difference among fish species (1-way ANOVA, p > 0.05) in the AEs of Am, Cd, Cs, or Zn. This is in marked contrast to the relative uptake of these metals from the dissolved phase, for which concentration factors in $S$. canicula are generally higher than those in Psetta maxima, at times by 1 or 2 orders of magnitude (for $\mathrm{Zn}$ and Am, respectively) (Jeffree et al. 2006). The absence of appreciable differences between $P$. maxima and $S$. canicula in their assimilation of metals from food observed here supports the assertion (Jeffree et al. 2006) that $S$. canicula accumulates metals more effectively than $P$. maxima from the dissolved phase because of other taxonomic characteristics, viz. their placoid scales, the components of which (collagen, glycosaminoglycans, and apatite) display a high affinity for metal ions, and the thick collagenous dermis typical of sharks.

Co and $\mathrm{Mn}, 2$ redox-sensitive metals, were the only metals with AEs that differed significantly among species (1-way ANOVA, p < 0.05), with Co being lower for Scyliorhinus canicula than for the 2 teleost species, and Mn being higher for Psetta maxima than for the other 2 species. The relatively high AE value for Mn in P. maxima after dietary exposure agrees with the exceptionally high retention of $\mathrm{Mn}$ in P. maxima after aqueous exposure (Jeffree et al. 2006). These findings indicate that the digestive tracts of fishes may differ in their digestive enzymes and, particularly, in their redox potentials. Differences in the reducing power of guts similarly accounted for differences in metal assimilation among bivalve species (Griscom et al. 2002a). Though there is very little information available on the digestive physiology of elasmobranch fishes, recent work highlights the complex integration of the ionoregulatory function in the digestive tracts of sharks (Wood et al. 2007), involving the selective absorbtion and exclusion from various compartments of the shark's digestive tract in order to maintain blood plasma $\mathrm{pH}$ and osmolarity. These processes do not occur in teleost fishes, and could indeed affect the absorption of metal ions during the digestive process in sharks.

Literature values of efflux rates of metals from marine fishes are even scarcer than those of assimilation efficiencies, but our values are similar to those in earlier studies which relied on crustacean prey. For all metals in the present study, we report $k_{\mathrm{e}}$ values ranging between 0.001 and $0.019 \mathrm{~d}^{-1}$ for the 3 predator species. An interspecies comparison of efflux rates reveals relative homogeneity in loss rates, with no significant differences observed for any of the metals in the 3 species under study. Our values for Cs (0.008 to $\left.0.019 \mathrm{~d}^{-1}\right)$ are slightly lower than previously reported values (0.020 to $0.023 \mathrm{~d}^{-1}$; Zhao et al. 2001), as are our values for $\mathrm{Cd}\left(0.009\right.$ to $0.019 \mathrm{~d}^{-1}$, compared with 0.03 to $0.07 \mathrm{~d}^{-1}$; Baines et al. 2002) and Am (0.003 to $0.009 \mathrm{~d}^{-1}$, compared with $0.04 \mathrm{~d}^{-1}$; Baines et al. 2002), but our values for $\mathrm{Zn}$ are very similar to literature values (Ni et al. 2000). Baines et al. (2002) found substantially lower efflux rates for $\mathrm{Cd}$ and $\mathrm{Se}$ in $88 \mathrm{~d}$ old striped bass than in $44 \mathrm{~d}$ old bass, suggesting that the slower metabolic rates associated with more mature fish affect the loss of assimilated metals. The fishes used in our study were both larger and more mature, perhaps accounting for these differences.

\section{Biomagnification of metals in marine fishes}

Experimentally determined TTFs from a controlled laboratory setting with minimal confounding environmental factors provide a way to indicate the potential for biomagnification in a particular food chain. Since the numerator of the TTF ratio (AE $\times$ IR) can be considered to be the uptake rate constant of metal from the dietary phase, TTF is analogous to the bioconcentration factor (BCF) that describes the extent to which a metal can be concentrated in an organism from the dissolved phase (Wang 2002). While BCFs of metals are widely reported in the literature, TTFs have not yet been characterized. In addition, while the biokinetic model used to calculate TTFs has been validated for diverse aquatic invertebrates (Wang et al. 1996, Fisher 
et al. 2000, Roditi et al. 2000, Griscom et al. 2002b), much work remains to be done with fish.

In general, TTFs were $<1$ for the metals in our study and for all 3 predator species, indicating that these metals should not biomagnify under normal conditions in predator fishes of this size feeding on a piscivorous diet. This is consistent with previous field observations, which generally show decreasing metal concentrations with increasing trophic level (Hornung et al. 1993, Canli \& Atli 2003, IAEA 2004). While several studies have noted the possibility of $\mathrm{Se}, \mathrm{Zn}$, and Cd biomagnification in certain marine food chains, the organisms considered were much smaller than the predators used in the present study. TTFs of $\mathrm{Cd}, \mathrm{Se}$, and $\mathrm{Zn}$ have been shown to decrease with increasing fish size (Zhang \& Wang 2007). Despite the increased AEs of larger carnivorous organisms, decreased weight-specific IR drives TTF values down with increasing fish size, so that for the metals examined in the present study, biomagnification in marine fish is unlikely.

Acknowledgements. We thank F. R. Oberhansli for laboratory assistance and M. Warnau for helpful comments. This research was supported in part by a grant from NSF (CHE0221934) to N. Fisher. The IAEA is grateful for the support provided to its Marine Environment Laboratory by the Government of the Principality of Monaco.

\section{LITERATURE CITED}

Baines SB, Fisher NS, Stewart R (2002) Assimilation and retention of selenium and other trace elements from crustacean food by juvenile striped bass (Morone saxatilis). Limnol Oceanogr 47:646-655

Brown JH, Gillooly JF, Allen AP, Savage VM, West GB (2004) Toward a metabolic theory of ecology. Ecology 85: 1771-1789

Canli M, Atli G (2003) The relationships between heavy metal $(\mathrm{Cd}, \mathrm{Cr}, \mathrm{Cu}, \mathrm{Fe}, \mathrm{Pb}, \mathrm{Zn})$ levels and the size of six Medierranean fish species. Environ Pollut 121:129-136

Croteau MN, Luoma SN, Stewart AR (2005) Trophic transfer of metals along freshwater food webs: evidence of cadmium biomagnification in nature. Limnol Oceanogr 50: $1511-1519$

Fisher NS, Reinfelder JR (1995) The trophic transfer of metals in marine systems. In: Tessier A, Turner DR (eds) Metal speciation and bioavailability in aquatic systems. Wiley, New York, p 363-406

- Fisher NS, Stupakoff I, Sanudo-Wilhelmy S, Wang WX, Teyssié JL, Fowler SW, Crusius J (2000) Trace metals in marine copepods: a field test of a bioaccumulation model coupled to laboratory uptake kinetics data. Mar Ecol Prog Ser 194:211-218

Griscom SB, Fisher NS, Aller RC, Lee BG (2002a) Effects of gut chemistry in marine bivalves on the assimilation of metals from ingested sediment particles. J Mar Res 60: 101-120

> Griscom SB, Fisher NS, Luoma SN (2002b) Kinetic modeling of $\mathrm{Ag}, \mathrm{Cd}$ and Co bioaccumulation in the clam Macoma balthica: quantifying dietary and dissolved sources. Mar Ecol Prog Ser 240:127-141
Hendriks AJ, Heikens A (2001) The power of size. 2. Rate constants and equilibrium ratios for accumulation of inorganic substances related to species weight. Environ Toxicol Chem 20:1421-1437

> Hornung H, Krom MD, Cohen Y, Bernhard M (1993) Trace metal content in deep water sharks from the eastern Mediterranean Sea. Mar Biol 115:331-338

IAEA (2004) Sediment distribution coefficients and concentration factors for biota in the marine environment. International Atomic Energy Agency, Vienna

Jeffree RA, Warnau M, Teyssié JL, Markich SJ (2006) Comparison of the bioaccumulation from seawater and depuration of heavy metals and radionuclides in the spotted dogfish Scyliorhinus canicula (Chondrichthys) and the turbot Psetta maxima (Actinopterygii: Teleostei). Sci Total Environ 368:839-852

Kennish MJ (1997) Practical handbook of estuarine and marine pollution. CRC Press, Boca Raton, FL

Luoma SN, Rainbow PS (2005) Why is metal bioaccumulation so variable? Biodynamics as a unifying concept. Environ Sci Technol 39:1921-1931

Mason RP, Laporte JM, Andres S (2000) Factors controlling the bioaccumulation of mercury, methylmercury, arsenic, selenium, and cadmium by freshwater invertebrates and fish. Arch Environ Contam Toxicol 38:283-297

Ni IH, Wang WX, Tam YK (2000) Transfer of Cd, Cr and Zn from zooplankton prey to mudskipper Periophthalmus cantonensis and glassy Ambassis urotaenia fishes. Mar Ecol Prog Ser 194:203-210

> Nieboer E, Richardson DHS (1980) The replacement of the non-descript term heavy metals by a biologically and chemically significant classification of metal ions. Environ Pollut Ser B Chem Phys 1:3-26

Peters RH (1983) The ecological implications of body size. Cambridge University Press, Cambridge

Reinfelder JR, Fisher NS (1994) Retention of elements absorbed by juvenile fish (Menidia menidia, Menidia beryllina) from zooplankton prey. Limnol Oceanogr 39:1783-1789

> Reinfelder JR, Fisher NS, Luoma SN, Nichols JW, Wang WX (1998) Trace element trophic transfer in aquatic organisms: a critique of the kinetic model approach. Sci Total Environ 219:117-135

> Roditi HA, Fisher NS, Sanudo-Wilhelmy SA (2000) Fieldtesting a metal bioaccumulation model for zebra mussels. Environ Sci Technol 34:2817-2825

> Savage VM, Gillooly JF, Woodruff WH, West GB, Allen AP, Enquist BJ, Brown JH (2004) The predominance of quarter-power scaling in biology. Funct Ecol 18:257-282

Schmidt-Nielsen K (1984) Scaling: Why is animal size so important? Cambridge University Press

Seebaugh DR, Wallace WG (2004) Importance of metalbinding proteins in the partitioning of $\mathrm{Cd}$ and $\mathrm{Zn}$ as trophically available metal (solid TAM) in the brine shrimp Artemia franciscana. Mar Ecol Prog Ser 272:215-230

Thomann RV (1980) Equilibrium model of fate of microcontaminants in diverse aquatic food chains. Can J Fish Aquat Sci 38:280-296

USEPA (2007) Framework for metals risk assessment. U.S. Environmental Protection Agency, Washington, DC

Volchok HL, Bowen VT, Folsom TR, Broecker WS, Schuert EA, Bien GS (1971) Oceanic distributions of radionuclides from nuclear explosions. In: Radioactivity in the marine environment. National Academy of Sciences, Washington, DC, $\mathrm{p} 42-89$

Wang WX (2002) Interactions of trace metals and different marine food chains. Mar Ecol Prog Ser 243:295-309

Wang WX, Fisher NS (1997) Modeling metal bioavailability for 
marine mussels. Rev Environ Contam Toxicol 151:39-65 Wang WX, Fisher NS (1999) Assimilation efficiencies of chemical contaminants in aquatic invertebrates: a synthesis. Environ Toxicol Chem 18:2034-2045

Wang WX, Fisher NS, Luoma SN (1996) Kinetic determinations of trace element bioaccumulation in the mussel Mytilus edulis. Mar Ecol Prog Ser 140:91-113

Wetherbee BM, Cortes E (2004) Food consumption and feeding habits. In: Carrier JC, Musick JA, Heithaus MR (eds) Biology of sharks and their relatives. CRC Press, Boca Raton, FL, p 225-245

Wood CM, Kajimura M, Bucking C, Walsh PJ (2007) Osmoregulation, ionoregulation and acid-base regulation by the gastrointestinal tract after feeding in the elasmo-

Editorial responsibility: Hans Heinrich Janssen, Oldendorf/Luhe, Germany branch (Squalus acanthias). J Exp Mar Biol Ecol 210: 1335-1349

Xu Y, Wang WX (2002) Exposure and potential food chain transfer factor of $\mathrm{Cd}$, Se and $\mathrm{Zn}$ in marine fish Lutjanus argentimaculatus. Mar Ecol Prog Ser 238:173-186

Zhang L, Wang WX (2006) Significance of subcellular metal distribution in prey in influencing the trophic transfer of metals in a marine fish. Limnol Oceanogr 51:2008-2017

Zhang L, Wang WX (2007) Size-dependence of the potential for metal biomagnification in early life stages of marine fish. Environ Toxicol Chem 26:787-794

Zhao XG, Wang WX, Yu KN, Lam PKS (2001) Biomagnification of radiocesium in a marine piscivorous fish. Mar Ecol Prog Ser 222:227-237

Submitted: August 13, 2007; Accepted: February 28, 2008 Proofs received from author(s): April 14, 2008 